\title{
Butler and Ethics
}

Edited by Moya Lloyd

\section{EDINBURGH}

University Press 
(C) editorial matter and organisation Moya Lloyd, 20I 5

(C) the chapters their several authors, 20I 5

Edinburgh University Press Ltd

The Tun - Holyrood Road

I 2 (2f) Jackson's Entry

Edinburgh EH8 8PJ

www.euppublishing.com

Typeset in II/I 3 Adobe Sabon by

Servis Filmsetting Ltd, Stockport, Cheshire, and printed and bound in Great Britain by

CPI Group (UK) Ltd, Croydon CRo 4 YY

A CIP record for this book is available from the British Library

ISBN $978 \circ 748678846$ (hardback)

ISBN $978 \circ 74867886 \circ$ (webready PDF)

ISBN $978 \circ 748678877$ (epub)

The right of Moya Lloyd to be identified as Editor of this work has been asserted in accordance with the Copyright, Designs and Patents Act 1988, and the Copyright and Related Rights Regulations 2003 (SI No. 2498). 


\section{Contents}

Acknowledgements vi

Introduction I

Moya Lloyd

I. Signifying Otherwise: Liveability and Language

I 5

Nathan Gies

2. Undoing Ethics: Butler on Precarity, Opacity and Responsibility Catherine Mills

3. Butler's Ethical Appeal: Being, Feeling and Acting Responsible Sara Rushing

4. Violence, Affect and Ethics Birgit Schippers

5. Sensate Democracy and Grievable Life Fiona Jenkins

6. Two Regimes of the Human: Butler and the Politics of Mattering

Drew Walker

7. The Ethics and Politics of Vulnerable Bodies Moya Lloyd

8. Subjectivation, the Social and a (Missing) Account of the Social Formation: Judith Butler's 'Turn' Samuel A. Chambers

Notes on Contributors 


\section{Sensate Democracy and Grievable Life} Fiona Jenkins

The ungrievable gather sometimes in public insurgencies of grief, which is why in so many countries it is difficult to distinguish the funeral from the demonstration. (Butler 20I2b)

The limit on what can be remembered is enforced in the present through what can be said and what can be heard - the limits of the audible and the sensible that constitute the public sphere. (Butler 20II)

There is a moment that Judith Butler several times alludes to in illustration of how she thinks about sensate democracy (see Butler 20I2a: I4; and Butler in Butler and Spivak 2007: 59-63). Illegal immigrants to the US, gathered in 2006 to protest at their precarious and unliveable situation, start singing the national anthem of the United States in Spanish; and in the middle of this comes the line 'somos equales', we are equal. The affirmation of equality of the stateless within the nation, and the performance of song in Spanish, transgress the boundaries of what it is thinkable for the nation to be. President George W. Bush declared in response that the national anthem of the USA cannot be sung in Spanish. But for all the power of his sovereign declaration, he does not 'make the anthem less sing-able'; indeed, what he responds to here is 'already out of his control' (Butler in Butler and Spivak 2007: 60-9).

Enacted as performative contradiction, the singing is demanding a move beyond the present legal articulation of rights, pressing against both sovereign and public understandings of what can and cannot 'be' (Butler in Butler and Spivak 2007: 69). A freedom is asserted that is without prior legitimation, and an equality performed that concerns, Butler tells us, 'a state of the social that takes form in discourse and other modes of articulation, including song' (Butler in Butler and Spivak 2007: 65). The right to rights so 
claimed sets up the problem of the 'we' of democracy, and the entitlement to protection the nation-state confers, as a perpetually and critically open question. Singing as a plural act, merging voices that remain different, ruptures the mono-lingualism of the nation, putting in motion the task of translation (Butler in Butler and Spivak 2007: 6I). Moreover, this demonstration emerges from conditions of precarity - unreliable conditions of life, the absence of the political and legal rights and protections that would make life 'liveable'; and there is something important pertaining to that about the singing itself, which is presenting plurality and embodiment in a performative form that cannot quite be spoken - belonging less to discursive language than to its limits, bearing traces of the living body as the social demand for protection and support.

It is possible, perhaps, to link this set of democratic gestures to a story about ethical violence that is at the heart of Butler's Giving an Account of Oneself (2005): a violence that arises from the impossibility of appropriating or taking up a relation with universal precepts. Ethical violence (in a formulation that is drawn from Adorno) arises from:

an operation of universality that fails to be responsive to cultural particularity and fails to undergo a reformulation of itself in response to the social and cultural conditions it includes within its scope of applicability. When a universal precept cannot, for social reasons, be appropriated, or when - indeed for social reasons - it must be refused, the universal precept itself becomes a site of contest, a theme and object of democratic debate ... [It] loses its status as a precondition of democratic debate. (Butler 2005: 6)

In what follows I shall suggest we think about this diagnosis of ethical violence primarily in terms of the need it implies for a continual remaking of spatio-temporal relations and social bonds in contemporary polities; and within this, the active appropriation of sacred 'universals' into the space of democratic contestation. In Butler's most recent books, the relevance for politics of the ethical framework she develops out of a critique of the subject - a critique that leads her to engage Adorno, Foucault, Levinas, Benjamin and Arendt - is increasingly evident. In particular, a preoccupation with the potentials of post-nationalist political formations guides much of her recent work. When she writes of Israel in Parting Ways - but equally, when she writes of the USA in Precarious 
Life - a profound criticism is directed at forms of nationalism that reject every limitation imposed by international law (Butler 20I2b: I77; Butler 2004: 98). Such nationalism, moreover, is animated by a defensive ethos that interprets all criticism as threatening sovereignty and the entitlement of the nation to existence (Butler 201 2b: I9). Thus in post-9/I I America, Butler tracks how public criticism of the War on Terror was heard as a repetition of that terror (Butler 2004: I). In the case of Israel, she marks how questioning the violent dis-appropriation of Palestinians from their lands is heard as abusing the memory of the Holocaust, casting doubt upon the right of Israel to exist, and thereby threatening Jews with a repetition of genocide (Butler 20I2b: 25). Universal values of freedom and democracy, the right of a people to self-determination, here enter into the legitimation of military violence, unconstrained by international law and inflicted on a population that is 'ungrievable'. The question becomes how the claim to embody the universal can be negotiated democratically, or translated into a mode of contestation and a problem of address. A key term Butler will use to think through this is 'pluralization'. ${ }^{1}$

The nation-state, attached to a sovereignty that is defined by militarily defended supremacy, exemplifies an ethical violence that finds hyperbolic expression in the imposition of unilateral terms on peoples who are either stateless or treated as if they were so, and are exposed to a re-iterative violence (Butler 2004: 33). Such action, in an exemplary way 'decides' who or what will be a human subject, a decision that often takes the form of bureaucratic license for legally unaccountable practices of detention, in a context where a lack of recognised national citizenship corresponds to exposure to the full violence of the nation-state. ${ }^{2}$ One way to parse Butler's analysis of what the stakes are here would be to say that a universality that is invoked as self-justificatory (often in a nationalist form) fails to recognise its specific mode of answerability - which is to reformulate itself in terms of the sphere of its applicability, that is, to be open to the historical and contingent sphere of its address. Hence on Butler's account, universal precepts must be understood as being addressed to those they would bind, and must enter into a political space of contestability when the question arises as to whether they can be appropriated or whether they must be refused (see Butler 20I 2a: I4). If that political space is not active, then universal precepts congeal into impositions. Law is undergone as a deathly thing, an ethical violence. A 
key political question thus becomes who is addressed by universal precepts, for instance the precepts associated with 'humanity'; and whether social conditions support that precept being appropriable by particular subjects (Butler 2005: 5). In this sense, maintaining a sphere of application for universals will reflect their critical deformability by the social and cultural conditions they encounter. Butler's term for this process of rupture and interruption, as aspects of a temporalised political task of universalisation, is 'translation' (201 2b: 8, 22-3).

Butler's reflection on ethical violence as an aspect of nationalism is precisely where Giving an Account of Oneself begins - a text often taken alongside Precarious Life as marking Butler's 'ethical turn' away from politics. Butler's discussions of the nationalism of the obituary have also been taken to signal a turn away from politics, most recently by Bonnie Honig, who argues that in Precarious Life, Butler endorses a

universal humanist ethics of lamentation in which the focus is on suffering. Sensitivity to shared vulnerability and exposure, Butler argues, can move us to cross the merely political lines of friend/enemy and inspire us to treat all lives as grievable and human. (Honig 2013: 42)

But this reading ignores the politics that, I argue here, is embedded in Butler's concern with the nationalism of grieving. ${ }^{3}$ Indeed, nationalism, on the account Butler draws from Adorno, will be anti-political precisely to the extent that it reflects an imaginary unity, an idealised collective ethos, which postulates a 'false unity that attempts to suppress the difficulty and discontinuity existing within any contemporary ethos' (Butler 2005: 3-4).

The analysis of ethical violence that Butler articulates speaks against Honig's reading of her post-200I work on nationalistic forms of mourning as offering a universalism premised on common humanity. Here Honig overlooks a crucial aspect of the politics of obituaries that Butler describes. For instance, one story Butler tells in Precarious Life is of a Palestinian citizen of the United States who submitted to the San Francisco Chronicle obituaries for two Palestinian families killed by Israeli troops. Informed by the paper that the obituaries could not be accepted without proof of death, he is told that a statement 'in memoriam' could be accepted. Yet upon submission of the memorial, this record was again rejected on the grounds that the newspaper did not 
wish to give offence (Butler 2004: 35). The sense of offence seems to assume a monopoly on suffering, the inadmissibility of comparative terms, reflecting not merely the exceptional and singular character attributed to national suffering (Butler 20II: 75, 90), but the feeling that universal conditions of justice are at stake in it. The newspaper's response could be said to generate the prohibition on content - which does not exist in any written form of law - insofar as it recites a given understanding of some established norms of national recognition, seeking to confirm them retroactively as absolutes. In a fine illustration of what Butler means by the 'anachronism' of the collective ethos (Adorno cited in Butler 2005:3-4), the 'offensiveness' thereby recited is one that presumes a given knowledge of what the culture of the United States is, what it must exclude or cannot tolerate, and aims to re-iteratively consolidate that understanding. Regarded as a gesture of contestation, however, the submission by the Palestinian citizen of the USA brings into the democratic sphere a question about who can be remembered - who counts - that evidences changes that are already underway in the composition of the membership of the United States, and even more fundamentally in the set of relations in which the nation is globally enmeshed. ${ }^{4}$ It is as just such a disturbance of the 'we' that the request for an obituary meets with opposition. Its import, then, cannot be analysed simply as a reflection of parochialism and partiality, set over against a given norm of 'universal humanity'. Rather the attempt to enforce what can be heard or seen, and so to limit what can be remembered, arises from rejecting a certain 'practice' of remembrance, one bound up with addressing and rethinking terms of co-belonging (Butler 2OII: 89).

I shall return to this politics of remembrance at the end of my discussion. For now, I am interested in tracking how ethics and politics are entwined in the argument Butler is making. According to Butler, something on the order of 'event' is foreclosed when an obituary is refused: 'In the silence of the newspaper there was no event, no loss ...' (Butler 2004: 36). The dehumanisation it effects is bound up with the 'unspeakable' limits of discursive life, rather than any positive content of discourse: 'There is less a dehumanizing discourse at work here than a refusal of discourse that produces dehumanization as a result' (Butler 2004: 36). What is meant by the 'refusal of discourse'? 'Discourse' is a weighty term for Butler, who stresses a phrase she takes from Levinas, that the 
encounter with the other's face is the 'situation of discourse'. In her discussion of that phrase she notes that this 'situation' is both a scene of address and a scene of conflict, in which the temptation to destroy the Other, to annul all relation, is thwarted at the level of responsibility by an irreducible dependency, a dimension of relationality - discourse - that exceeds the will (Butler 2004: I39). The way in which the 'situation of discourse' thus limits powers of decision, of agency or of prohibition, even limits the very capacity to kill the 'face', is vital to the account of obligation that Butler gives in this work (which is not, I think, based ultimately in 'ontological facts' of common precariousness or vulnerability ${ }^{5}$ even though it enfolds these).

When Butler writes that where there is no life, no loss, there also will have been 'no common bodily condition, no vulnerability that serves as the basis for apprehension of our commonality ... no sundering of that commonality' (2004: 36), it would be very easy to understand this as making reference to a universal human fragility, a common human condition which a parochial and exclusionary nationalism fails to heed. But I am suggesting that the 'refusal of discourse' is perhaps something different, something more immediately political. If we think about what happens when discourse is refused as beginning from the response to an event of contestation, an address initiated when the request was made by a Palestinian citizen of the United States that Palestinian lives be marked and mourned in the public sphere, then the salience of a dynamic and plural social ontology that subtends this scene might become more evident. A foreclosure, of the kind the San Francisco Chronicle engaged in, perhaps can be understood as seeking to disavow a new spatial configuration of the nation-state and an interruptive temporality that is always-already thwarting powers of sovereign decision to determine what can and cannot be (just as the demonstration by illegal residents of the USA introduces such disruption). In the refusal to acknowledge deaths as important, the newspaper is attempting to maintain a law of identity, boundary or self-sameness that anachronistically refuses new forms of potentiality, arising from emerging relations, or new possibilities of discourse.

To the extent that gestures in the public sphere can effect this mode of 'de-realization' of a life, then at issue is 'not just that a death is poorly marked but that it is unmarkable' (Butler 2004: 35). The 'unmarkable', however, so Butler tells us, is shadowed 
by its 'ontologically uncertain double', that which troubles our sense of reality. This 'double' that a foreclosure reacts to or 'apprehends' (meaning 'senses', but also 'seizes' - apprehends as a criminal is apprehended) exceeds what can be contained by established norms of appearance in the public sphere (Butler 2009a: 5, I I). In such phrases as 'unmarkable' or 'ungrievable' we should therefore note and try to understand in Butler's text a shift she is in effect performing from the censorialism of a sovereign prohibition on marking death (as in Creon's edict in Antigone) to a quasi-transcendental register. This is a register in which the prohibition ceases to function as the manifestation of law and is re-read as gesture, as sign and as reaction to conditions experienced as threatening to the project of maintaining a presumptively universal ethos. In the tension between these two gestures we might come to see the prohibition placed upon events that must not be seen, heard or known, as a response to the emergence of conditions that in fact challenge or trouble the confident application of the norm. Here demonstration or contestation enters to render the scene one of a potentiality residing within 'impossibility'. Thus the quasitranscendental 'haunted' or spectral dimension of prohibition should be taken seriously as registering the question of 'recognizability' in ways that open towards a politics of contestation. As Butler puts the political question that follows:

The problem is not merely how to include more people within existing norms, but to consider how existing norms allocate recognition differentially. What new norms are possible, and how are they wrought? What might be done to produce a more egalitarian set of conditions for recognizability ... to shift the very terms of recognizability to produce more radically egalitarian results? (Butler 2009a: 6)

Here, I suggest, Butler's critique and its concern for more 'equally grievable' and thus 'liveable' lives integrates these terms with the forms of provocation or questioning from which such equality might emerge - not as a moral and universal given whose proper subjects are already known, but as a provocative claim arising from material and social conditions of existence brought into tension with social practices reflecting the mode of their articulation as systemic inequalities. These contestatory claims find one kind of model in the scene of demonstration from which I began. Thus in a sensate democracy, it is not only established authority, 
such as that of the nation-state, which gives meaning to what is 'grievable' or 'recognizable', but also what escapes it - the emergent claim, or the performativity of address, whereby the question of how to 'take up' a norm in a critical way becomes salient.

The temptation to be avoided here is to read such terms as 'grievability' as though they simply tracked the prohibitive or censorial power to withhold recognition - to mark certain lives as mattering, while refusing that status to others. The countervailing desire to extend recognition in more inclusive ways, without offering a critique of the social and political conditions under which inequality and difference are established (as in the universal humanism Honig argues Butler now leans towards) would also fail to offer a critique of the mode of power expressed in the nationstate, and of the forms of social relation that a nationalism posing as the universal facilitates. A pluralising critique must instead aim to open up a relation with dominant norms that defies their presumptive status as necessary schemas for the recognition of value. This project, I am arguing, is at the core of what Butler calls 'sensate democracy'. The persistent shift from discussion of recognition to discussion of the 'recognizable', or indeed, from grief to the 'grievable' in Butler's texts, thus register a plural and dynamic space of relations, a potentiality and conditionality, not simply a unilateral operation of power. How is that potentiality and conditionality to be interpreted? How do we challenge the way in which a normative ideal of recognition (perhaps a nationalist one) comes to colonise recognisability?

\section{Pluralisation and obligation}

Contrasting with the nation-state-centred work of the normative division of life, in her essay 'Is Judaism Zionism?' lines an account of a pluralising process. This implies marking how identity always remains in relation to that which is placed 'outside', thus to an alterity that not only can never be assimilated, but disrupts and interrupts any established understanding of who 'we' are (be that the universalised 'we' of humanity, of a religious community or of the nation-state). Pluralisation is not pluralism in the sense of respecting fidelity to some pre-given cultural particularity; nor is it fidelity to the legitimating universality claimed by the nation-state. Plurality, Butler tells us, can have no given or established form; it is antithetical to the work of creating 
boundaries in establishing an inside and an outside, for plurality 'cannot be exclusionary without losing its plural character' (Butler 2OII: 84). Pluralisation is a process that always invokes a potential condition as well as an actual one (Butler 20I I: 84, compare Connolly 2005). Citing Arendt approvingly in support of this idea, Butler suggests we might take from her the thought of man (subject of universal rights) not as individual but as a 'situation of community and equality, both of which are preconditions of change and building agency ... this notion of man doesn't define a priori features or properties of an individual but actually designates a relation of equality among beings' (Butler in Butler and Spivak 2007: 57, my emphasis).

Political action, according to this conception, is action that first and foremost seeks to establish equality in the sense of plurality, as the 'minimal condition' for being politically efficacious. An ontological condition is in this way bound to a political aspiration towards equality in relations. The ontological condition (which in a key sense is conditionality, as I explain further below) might be thought to signal the being of potentiality that is at stake in the performativity of the process of pluralisation (see Butler in Butler and Spivak 2007: 57). Singing the US anthem in Spanish might be one demonstration of what this means as political action.

On this pluralising understanding of politics, 'equal protection, or indeed equality, is not a principle that homogenizes those to whom it applies; rather, the commitment to equality is a commitment to the process of differentiation itself' (Butler 20II: 85). Differentiation might itself be thought of as the way in which the 'event' or singularity is brought to appearance; so that a process of differentiation does not begin with the categorical statement of a universal ('everyone') but rather makes the 'every-one' appear, as aspects of a co-habiting plurality, or as relationality. The implication of the 'I' in social relations is critical here, as is the ethical problem of how the 'I' takes up those relations, a question central to Butler's ethics, which I discuss more fully in the final section. Self-differentiation - the bringing to appearance of the 'one' or the event - also fractures the collective subject or 'we'. As I develop this argument, I will also suggest that Butler puts this thought precisely in terms of obligations that derive from our 'unchosen' ways of being in relation with one another, impinged upon and dependent, 'precarious'. Such obligations, she argues, cannot be captured by speaking of what 'we' owe to others, since that 'we' is 
from the start 'interrupted' by the alterity it would (or would not) recognise. And thus she concludes, again aligning her thought with that of Levinas, 'the obligations "we" have are precisely those that disrupt any established notion of the "we" (Butler 2009a: I4).

This account of obligation will resonate with how Butler follows but also critically departs from Levinas in rendering the 'situation of discourse' (Butler 2004: I39) by locating the situation of discourse within the sphere of appearances, and thereby in the contested spatio-temporality of the public sphere. In Frames of War Butler specifies that her use of the term 'ontology' refers to what it is to be a body that is 'given over to others' in a world that is socially and politically organised in differential terms to 'maximize precariousness for some and minimize precariousness for others' (Butler 2009a: 2-3). Sensate democracy requires the cultivation of 'conditions of responsiveness' that transgress this form of organisation. If there is to be a claim of non-violence (as Levinas proposes) that is not 'meaningless' (a criticism, this hints, that he may be exposed to) Butler argues that there must be an essential alliance between generating the conditions under which the apprehension of the ethical claim of precarious life becomes possible, and criticism of the work of norms that work to perform a division, structuring the field of appearance so as to differentiate the lives that are 'liveable' and 'grievable' from those that are not (Butler 2009a: I 80). Politically, it becomes vital to support 'those modes of representation and appearance that allow the claim of life to be made and heard' (Butler 2009a: I 8I). But the kind of political work this is understood to be will depend upon how in turn we understand the structure of the field of appearance, and of agency with respect to its hegemony.

I have suggested we find one exemplar of this politics in the performativity of singing the US anthem in Spanish, as it manifests plurality in an act of claiming equality. Obligation is generated here in a sense that tracks the points made above - an obligation to see and hear that breaks with a prohibitive framework. It is important that insofar as the ethical claim of non-violence is also registered within this act, it falls as obligation upon the disrupted 'we' (Butler 2009a:I4); and so it will reveal its 'subject' (the one to whom the claim is addressed) less as an individual who must independently decide on a course of action, than a part of that sociality from which the 'we' arises, that is, as 'a being bound up with others in inextricable and irreversible ways, existing in 
a generalized condition of precariousness and interdependency, affectively driven and crafted by those whose effects on me I never chose' (Butler 2009a: I 80).

The ontology elaborated by Butler in this way reflects that sociality from which a 'we' arises, including the sense of this as a dynamic and fractured space of iterability. Sociality structures norms as imperfect, incomplete, temporal and heterogeneous, thus contestable and deformable. Here it is also worthwhile to consider how Butler specifies the meaning she lends life's 'precariousness' in terms of a modality of being, not a property of beings - a way of thinking that aligns what the term means for her with this temporalised and dynamic social ontology of normative life. For precariousness, Butler tells us, is simply the ontological condition of being conditioned, and this can be posited as a generalised condition - indeed, as the very mode of equality - precisely because it is not 'proper' to one individual or another (Butler 2009a: 23). Precariousness - and here Butler parts company with Arendt - traverses the boundary between the human and the animal, the social and the environmental conditions of sustainable and liveable life. It is not 'proper' to the human. It cannot properly be recognised (Butler 2009a: I3). Rather, 'it can be apprehended, taken in, encountered, and it can be presupposed by certain norms of recognition just as it can be refused by such norms' (Butler 2009a: I3). It is in this sense 'inassimilable' (Butler 2012b: 23). Far from being what we already recognise as the 'common condition of humanity', under political conditions that press us to 'a dissolution and reformulation of the process of universalization' precarious life is the very site of the 'inassimilable' that perpetually bears the potential to break norms apart. And only thus, by registering and engaging the inassimilable, does 'universalization renew itself within a radically democratic project' (Butler 20I 2 b: 23).

It is important, then, to notice how conditions and relations are thematically linked to life and to obligation in Butler's account, and drive the sense of contestability. The 'a priori' of recognisability (in the 'sovereign' sense) becomes temporalised, as conditions of intelligibility for what counts as a 'life' emerge as politicised and contestable (Butler 2009a: 6). We saw earlier how this shift plays out in the demand for a Palestinian obituary. But it also explains, I think, why in Frames of War, Butler strongly emphasises the way her argument moves between epistemological and ontological registers. Whereas at the epistemic level, operations of power 
aim to 'delimit the sphere of appearance itself' even if they fail to 'unilaterally decide it' (Butler 2009a: I), at the ontological level it seems we touch on or apprehend the precarious 'being' of a life; mortality, vulnerability but also temporality and potentiality. Although it is impossible to refer to this life without reliance on the rubrics of power, life nonetheless exists at 'a limit internal to normative construction itself, a function of its iterability and heterogeneity' (Butler 2009a: 4). Life is thus both the condition of the norm bearing its 'crafting' power and that which 'limits the finality of any of its effects' (Butler 2009a: 4).

In this context, Butler stresses two political dimensions of the 'recognizability' that precedes recognition. First, as Foucault argued and as I discuss further below, the norms that prepare or establish a subject for recognition, making recognition possible, also 'induce a subject of this kind' (Butler 2009a: 5) - that is, a subject who takes up a certain relation with normative life, a relation that is at once compelling and critical. Secondly, a contestation in and around the normative framing of life is constantly taking place, indeed, the 'taking place' of life and death - the eventfulness we might say, of existence, itself - 'calls into question the necessity of the mechanisms through which ontological fields are constituted' (Butler 2009a: 7). In this way the normative inscription of life is 'haunted'; a thought we might be inclined to read 'ontically' in terms of what is excluded from recognition, but that may be better registered ontologically (or better again, 'hauntologically' in Derrida's phrase) as concerning the apprehension of foreclosed potentials, indeed of the very temporality that means that 'every normative instance is shadowed by its own failure' (Butler 2009a: 7). If the normative framing of life is only given temporally, then this temporality is that of a living relation with norms (Butler 2005: 5) - the critical space in which the norm is 'taken up' or refused. Moreover, insofar as the modality of power of norms is re-iterative (that is to say, the norm must be re-instated by those who live within its frame), this 'uptake' of relationality can be construed as implying a dynamic space of perception, and one in which the 'unrecognizable' fleetingly appears.

We might return again from this analysis to the question of the politics at stake in the attention Butler pays to the nationalism of mourning. If, as Butler tells us, the 'apprehension of grievability precedes and makes possible the apprehension of precarious life' (2009a: I 5), then we should hesitate before assuming that such 
'grievability' is only or always the individualised logic of recognition that Butler's example of the obituary might at first seem to suggest. Rather, it may be helpful to think of the way that Butler engages together the themes of grievability (which risks seeming like a nation-state sanctioned attitude) and precariousness (which risks seeming like a given bodily condition, or 'ontological fact') as aspects of a process of pluralisation opposed to the divisive work 'grievability' does in the nation-state. Cast as the ethico-political work she is herself practising, we might consider how her discussion of the obituary tarries with the limit of recognition - with those who are 'unburied, if not unburiable'; those we apprehend, rather than 'know', perhaps as we apprehend the 'gaps' in public record (Butler 2004: 34) without necessarily seeking thereby to fill them with content. Such apprehension becomes the basis for a critique of given norms of recognition (Butler 2009a: 5). She is insisting here on the historical and political production of 'recognizability' over and against the sense of these norms as $a$ priori conditions of appearance (as a nationalist frame, posing as universal, may well seem to be). Where 'grievability' is thought in the mode of critique, the plural conditions of social existence become activated within her account, conditions that open a life to 'exposure' - that is, our exposure and dependency before others as well as their dependency upon and exposure to us.

\section{Ethics as critique}

In the Acknowledgements to Frames of War, Butler directly specifies her project as one of critique, with a particular focus on sociality as what binds and connects us. She writes:

The critique of war emerges from the occasions of war, but its aim is to rethink the complex and fragile character of the social bond and to consider what conditions might make violence less possible, lives more equally grievable and hence, more livable. (2009a: viii)

What does it mean for this project of re-thinking the 'social bond' to be one of critique? In the concluding pages of Precarious Life, critique is tasked with creating a sense of the public in which oppositional voices of dissent can flourish, alongside practices of cultural translation that work against the consignment of the face of the other to the sphere of the unintelligible - as the 'ungrievable' 
or 'already dead' (Butler 2004: I5I). An intimate link is proposed between the discourse that comes to audibility in the public sphere, and the legal, social and material conditions that support and protect life. The 'life' in question, I have been arguing, is 'relational' - in relation to others, to an environment, to norms, to itself - thus conditional and conditioned. Here, I suggest, Butler engages in a critique that, like Kant's, examines conditions of possibility of appearance, but also goes beyond him in asking how denying the conditionality of action, or foreclosing acknowledgement of relationality, becomes a mode of doing violence; asks, indeed, how the elements that stabilise Kant's notion of 'conditions' by reference to a subject who is an 'I' might mis-locate the proper terms of a social critique. Here again we are on territory mapped out as ethical in Giving an Account of Oneself.

Butler, indeed, devotes considerable attention to describing critique as an ethical and political practice in Giving an Account and elsewhere. Thus in an essay on Foucault, for instance, Butler first recites how Foucault, like Adorno, diverges from Kant in refusing to assimilate critique to a practice that would secure judgement. For Adorno, if the critic is not to be separated from the social world, critique must operate as part of a praxis that would not simply apply already constituted categories to particulars but 'apprehend the ways in which categories are themselves instituted, how the field of knowledge is ordered, and how what it suppresses returns, as it were, as its own constitutive occlusion' (Butler 2002: 213, compare 2005: I33). In alignment with these gestures, the question Foucault addresses in his own well-known essay - 'What is critique?' - does not in fact simply ask what critique is, but 'enacts a certain mode of questioning which will prove central to the activity of critique itself' (Butler 2002: 2I 5). Over against Habermas, who finds that critique cannot deliver the kind of normative orientation we need if we are to make judgements about social conditions, Foucault insists upon an engagement in critique that is no less Kantian in interrogating epistemological limits. Here Butler suggests that Foucault's particular way of approaching ethics displaces the question Habermas insists upon as the locus of normative judgement - 'what are we to do?' - in favour of paying attention to a prior set of questions, examining the very formation of the 'we', and thus the sense in which the 'we' might be considered to be known or its action possible (Butler 2002: 214). 
The question, Who are we? is posed in this conception of critique that is indebted to Foucault, as prior to the question, What should we do? As such it articulates the question of the social bond and of the 'action in concert' that Arendt delineated as political. 'Who are we?' is not an abstract question, yet the temptation will always be to answer it in identitarian terms, as though the 'we' were simply looking for a particular to give it content, or as though it conjured a given membership (subsumed under the categories provided by the nation-state, say).

How might an ethics respond? If, as Foucault holds, critique seeks not to evaluate its objects, but to bring into relief the framework of evaluation itself, it induces what we might think of as a reflection on the conduct of evaluation. Critique is formulated as a virtue, in the sense that it belongs to an ethics that cannot be fulfilled by following objectively formulated rules or laws, but requires being in excess of them, demanding that a critical relation to norms is practised. Experiences can then be properly described as 'moral' not simply because they prohibit or command but because they open the very relation to law that the practice of critique as questioning enacts (Butler 2002: 216). What critique interrogates are 'settled domains of ontology' which constrain our understanding of what is possible; and it does so insofar as a living relation to given codes of conduct implies the formation and transformation of the self: 'To be critical of an authority that poses as absolute', Butler writes, 'requires a critical practice that has self-transformation at its core' (2002: 218). Again, the point can be adapted to speak to the account of ethical violence as an anachronistic nationalist violence, and thus to the demand for a thinking that is post-nationalist or inter-nationalist. But this is on particular terms: social critique construed thus is a mode of questioning that dislodges the moral primacy of passing judgement, and interrogates something prior to that - the living (in)stability of discourse that supports, sustains, but also undermines normativity. In the same way, I will suggest, the questions Butler poses when she initiates a critique of war have precisely this concern for transformation at their core, a transformation - or transformability - that enters the very conditions of existence, and that we should hear at work in the ambition to render life 'more liveable'.

In the term 'sensate democracy', an openness to transformation is perhaps already registered; we may hear in it at once the idea of attention to what is felt, experienced or lived - the world 
that appears or is 'apprehended' as living; and that which is itself feeling, experiencing, living - the plural subject or 'we' of democracy, and this 'we' perhaps conceived less as a subject than as an openness to a world in transformation, sensing and sensed. This broadening of the 'sensate' to connote what is living, and thus sensing and sensed, suggests a need to be wary of any suggestion that Butler is somehow concerned with a politics of feeling or sentiment alone, as if her idea is simply that these might be mobilised to widen the circle of regard for fellow human beings. There is a deeper ontological concern at work in Butler's reflections, a concern with the 'crafting' of the subject or of the body, as that which can be 'felt' or can 'feel' (or 'cannot' be felt, cannot feel) in iterations of the normative that may be deformed and reworked by their medium. We might indeed name the 'sensate', rather than any more abstract notion of temporality, as the 'limit internal to normative construction itself' (Butler 2009a: 4). If 'life' always exceeds the normative conditions of its recognisability, as Butler claims, it is perhaps because life is the locus of a crafting that is at once active and passive, an iteration by which a temporality is in play that does not begin with the subject but disorientates and dispossesses it, limiting the finality of any of the effects of normative construction - a precarious life.

Likewise the renewal of the social bond described by Butler as 'sensate' is not abstract; it emerges at specific sites, as we might imagine in the reclaiming of the street and in the articulation of plurality in a song that by virtue of containing a pressing contradiction, can operate as a mode of address. The importance of the ethical for Butler as it emerges in her discussion of Derrida is that it marks a critical temporality, one that gives the rhythm to any project of collective self-making. At stake in this is the specific futurity that Derrida marks with the 'to come', which Butler glosses as inaugurated by the 'fact of linguistic address and this way of offering the future'; and as the foundation not only of law, but politics, insofar as the 'gift of speech makes possible the emergence and sustainability of the "we"' (Butler 2009b: 303). As the relation of address, the ethical 'inaugurates, time and again, the political' - and thus the 'to come' is the condition of possibility of politics itself (Butler 2009b: 304):

The unrealizable is also the condition of possibility (what Derrida might call the 'impossible condition of possibility') for events and 
for persons, and in this sense, what is 'to come' is already there, even always, as the condition of possibility for what exists. (Butler 2009 b: 305)

The questions of what or who we are in relation with, and how or whether we take up a relation with norms, are at the core of this ethico-politics. This is a point that Butler makes particularly clearly in her Adorno Prize Lecture of 20I2. When Butler turns in Frames of War to elaborate a 'bodily ontology' to defend a claim about the obligations she holds are imposed upon us by the 'precarity of life', she is careful to specify how the term 'ontology' is for her located within a 'political organization and interpretation' (Butler 2009a: 2). In her lecture, Butler likewise embeds a vital set of considerations about the need to attend to life in its dependency on material and social conditions of survival within an equally insistent responsibility for invigorating the socio-political sphere where moral reflection arises. If 'morality from its inception is bound up with biopolitics' this is because the moral question is: 'how do I live this life within the life, the conditions of living, that structure us now?' (Butler 20I2a: Io) The question, which like Foucault's is concerned with the conduct of evaluation, seeks to render moral reflection inseparable from the categories, power differentials and structures in which my 'living' is embedded. A moral reflection that takes account of what it is to be living, implicates the subject who asks 'how to live a good life?' in a social inquiry into the sustaining contexts precisely of reflection and action. To ask, with Adorno, 'how to live a good life in a bad life' - that is, in a world whose categories and structures produce effacement and inequality (Butler 20I2a: I I) - is to allow the problem of how I affirm my own life as a life, to resonate with the question of how the affirmation of life occurs and is distributed socially. Moreover, it is to accept that reflection is inseparable from dependencies, or that its very form has to do with conditionality, with beingconditioned. Reflection is in this sense itself 'precarious'. It is the way in which my life is bound up with others, the way in which my life 'is and is not my own', that makes critique of the biopolitical order a 'living issue for me':

This practice of critique is one in which my own life is bound up with the objects I think about. My life is this life, lived here, in the spatiotemporal horizon established by my body, but it is also out there, 
implicated in other living processes of which I am but one. Further, it is implicated in the power differentials that decide whose life matters more, and whose life matters less ... (Butler 20 I2a: I I)

At the same time, relationality bears an irreducibly discursive aspect, and constrains and enables reflexivity - 'the only terms by which this "I" grasps itself are those that belong to a discourse that precedes and informs thought without any of us being able to fully grasp its working and its effect' (Butler 20I 2a: I I). Indeed, it is in a sense towards an order of discourse that is inseparable from the material conditions of life that Butler invites us to turn in practising critique. When a life is 'ungrievable' it is because there is 'no present structure of support that will sustain that life, which implies that it is devalued, not worth supporting and protecting as a life by dominant schemas of value' (Butler 20 г2a: Iо). For this reason, we are led to critique as a relationship with those schemas, as a problem of how we live them. Our obligations, accordingly, are not to this or that life, but to the 'generalizable conditions' of life (Butler 2009a: 22-3) - that is, to the 'condition of being conditioned' (Butler 2009a: 23) or 'precariousness'. This in turn implies an ongoing process of universalisation (a pluralisation) which might well be contrasted with the universalising form of Kantian moral law.

Thus when Butler writes 'the precarity of life imposes an obligation on us' (Butler 2009a: 2), I have taken it that a crucial part of that imposed obligation is the obligation of dissent; that is, of living a practice of critique, ethically and politically, which as such engages the excess of life over given epistemological limits, and moreover suspends the ontological grounding of the subject in and by initiating transformation. Obligation arises from the very texture of dependency and sociality, and is 'constitutive obligation' in the sense that such dependency and sociality, far from being facts or givens by which the necessity of certain actions would be morally entailed, instead themselves immediately demand to be 'lived'. Conditionality is a 'living issue for me' because I cannot escape taking up some relation with it, be it to re-establish existing conditions, or to open them to critique (Butler 20I2a: II).

Illustrating this thought leads to a vital insight into the conditional limitation ethics imposes on every sovereign decision. Reading Arendt's account of Eichmann's crime, Butler condenses it to this precept, which chimes closely with her rendering of 
Levinas's account of the 'face' as that which I am unable to kill:" 'no one has the right to decide with whom to co-habit thus everyone has the right to cohabit with equal degrees of protection' (Butler 20II: 85, my emphasis). If we thought about this precept in terms of the problem of the conduct of evaluation, we might notice the critical role played in the argument by the limitation Butler follows (and adapts) Arendt in placing on the right to decide (it is analogous to the limitation imposed by the Levinasian face - that it cannot be killed). ${ }^{8}$ This claim, 'No one has the right to decide with whom to co-habit' is not simply articulated as a free-standing axiom. Rather, it is cohabitation itself that limits decision. The limitation on decision reflects conditionality; and to seek to choose where there is no choice is to seek to destroy the conditions of social and political life. In deriving from this the 'right to cohabit', Butler is performing a pluralisation, which involves circumscribing the unilateral right to decide through reference to its own conditionality - its existence within a plural space. ${ }^{9}$ Also in play here is the sense that there must be room made for the 'conduct' of evaluation itself, the relation with the norm. Thus we are obligated not only to preserve the lives of the others with whom we cohabit, but 'the plurality of which they form a part' (Butler 20II: 85), and this transforms the principles by which we act into a 'speaking for' plurality - a political gesture of equality - which contrasts with simply deriving the universal from a given understanding of who properly belongs in the set (all rational human beings, for instance).

In this sense the process of differentiation does not begin from the universal category 'everyone' but rather makes 'everyone' appear, the 'one' whose relation with the norm invites, in Foucault's terms, a conduct of evaluation, and who thus practises critique as a virtue. The obligation to preserve plurality is then an obligation that binds us in the absence of properly 'belonging' to a normative field populated by the universal truth of a common humanity, moving along a teleologically established path of progress. That is why it can be characterised by Butler both in terms of proximity, adjacency, up-againstness - a 'convergent' condition, rather than a 'common' one (Butler 20II: 88); and in terms of an interruptive temporality, the interruption of one time by another - precisely where a time 'cannot be' (Butler 20I I: 88). The 'measure of a life' proper to grievability involves this struggle, as Butler remarks, reading Benjamin: 
Remembrance attends to the ways that history works now as well as what opens up within that reiterated history to reclaim the history of the oppressed. The measure of a life is the way that history continues to act in the present which means, of course, that the presence of those contingent moments accumulate, chances or wagers, flash upon flash, a struggle for the past which is the only way to transform the present ... (Butler 20I2b: II3)

The singing in Spanish of the US national anthem does not only contest the limits defining citizenship; it also, one might think, practices a certain politics of remembrance of loss and of the potentialities of realising loss that can be directly aligned with the political demand for an obituary. The question of how the limit of what can be remembered is enforced in the present (Butler 20II: $89 ; 2004: \mathrm{xx}$ ) provides one schema by which to analyse contemporary, yet anachronistic, formations of the nation-state - and it runs throughout Butler's discussions of 'grievability' and of whose life is grievable under contemporary conditions. But I have argued that there is another, countervailing politics at stake in every account she gives of the 'gaps' in public record of lives lost. Here, rather than simply seeking to fill in the gaps, we should apprehend the emergence of a contest, a demand for pluralisation. This demand is given as a living history that does not 'enforce the present', but conversely 'acts in the present'. A politics of remembrance, then, poses the democratic questions of translation, and of the applicability of law to life, reminding us of the necessary interruption of one space of appearance, one sense of space-time continuum with another that disrupts it. To practise remembrance in the Benjaminian sense might give rise to a new concept of citizenship, Butler tells us - one that arises from, but is against dispossession and precarity (Butler 20II: 90). Such remembrance insists upon registering the 'impossible' co-habitation of peoples that is already taking place, and that demands acknowledgement, mourning, and affirmation in the company of those plural others who make up the political world.

\section{Notes}

I. William Connolly's account in The Ethos of Pluralization (2005) is an important source, but so too is a reading of Arendt developed in Parting Ways, chapters 5-6. 
2. See 'Indefinite Detention', chapter 3 of Precarious Life (Butler 2004). The political situation that makes Guantanamo possible thus already has a background that finds its diagnosis in Arendt's formulation of what placed nationalism above the law: that 'the same nation was at once declared to be subject to laws which would supposedly flow from the Rights of Man, and sovereign, that is bound by no universal law and acknowledging nothing superior to itself' (Arendt $195 \mathrm{I}$ : 230).

3. Honig is not alone. There are many readings highly critical of Butler's 'ethical turn', such as those offered by Slavoj Žižek (2006), Lauren Berlant (2007), Catherine Mills (2007) or Jodi Dean (2009), as well as more sympathetic readings, such as that of Ann Murphy (20II). Butler's demand in her works since $200 \mathrm{I}$ that grief become a resource for non-violence, her apparent belief that we might derive normative claims from a common bodily condition of vulnerability, and her mobilisation of aspects of a Levinasian ethics of the face, have all led to charges of political naivety, which Dean labels as Butler's 'prescriptive niceness', the demand of ethical openness to the other. Dean's objections to this 'niceness' are in no way offset by Murphy's sympathetic account of what the ethics might be. Murphy argues that we find in Butler's work a re-invented humanism that would combine the 'ontological truism' of corporeal vulnerability with a response to the ethical provocation of unequally distributed precarity, implying we might learn to perceive the generalisability of precariousness (see Murphy 20II: 582). The resulting ethic is exactly that attacked by Dean as apolitical. Here I seek to offer an alternate account of the 'ontological' obligation Butler relies upon in these arguments.

4. Compare Butler's discussion in Is Critique Secular? (2009c: I33).

5. Ann Murphy, for instance, argues that the sense of ethical obligation that would call us to remedy the conditions of unequal distribution of grievability rests on affirming precariousness as a common condition; the key claim is that 'ontological facts about the human body - particularly its vulnerability and exposure to violence - might be read as indicating certain obligations' (20I I: 577). Murphy thus suggests that Butler is proposing the obligation to 'ameliorate suffering', arising from the common condition of precarious life, and that it is this 'common condition' that renders the egalitarian dimension of her argument the primary normative claim (20II: 58I). This is an apolitical reading of Butler that would fit very well with the sort of criticisms that Honig levels.

6. This essay appears in The Power of Religion in the Public Sphere 
(Mendieta and VanAntwerpen 20II), and is largely reproduced in Parting Ways (Butler 20I 2b).

7. Parting Ways (Butler 20I2b), Chapter 2 passim.

8. Butler writes: 'An obscure point of contact between Levinas and Arendt guides me here' (20I2b: 23).

9. There is a parallel discussion of the 'right to life' in the introduction to Frames of War (Butler 2009a: 20) which argues that there is no 'decision' without a field of its application, conditions of validation and authorisation; discursive props that are sedimented in material arrangements.

\section{References}

Arendt, Hannah (I95I), The Origins of Totalitarianism, New York: Harcourt Brace Jovanovich.

Berlant, Lauren (2007), 'Nearly Utopian, Nearly Normal: Post-Fordist Affect in La Promesse and Rosetta', Public Culture, I9: 2, 273-30I.

Butler, Judith (2002), 'What is Critique?: An Essay on Foucault's Virtue', in David Ingram (ed.) The Political, Oxford: Blackwell, pp. 21 2-26.

Butler, Judith (2004), Precarious Life: The Powers of Mourning and Violence, New York: Verso.

Butler, Judith (2005), Giving an Account of Oneself, New York: Fordham University Press.

Butler, Judith (2009a), Frames of War: When Is Life Grievable?, New York: Verso.

Butler, Judith (2009b), 'Finishing, Starting', in Pheng Cheah and Suzanne Guerlac (eds), Derrida and the Time of the Political, Durham, NC and London: Duke University Press, pp. 29I-306.

Butler, Judith (2009c), 'The Sensibility of Critique: Response to Asad and Mahmood', in Talal Asad, Wendy Brown, Judith Butler and Saba Mahmood, Is Critique Secular?: Blasphemy, Injury, and Free Speech: The Townsend Papers in the Humanities, No. 2, Berkeley, Los Angeles and London: University of California Press, pp. IOI-36.

Butler, Judith (20II), 'Is Judaism Zionism?' in Eduardo Mendieta and Jonathan VanAntwerpen (eds), The Power of Religion in the Public Sphere, New York: Columbia University Press, pp. 70-9I.

Butler, Judith (20I2a), 'Can one lead a good life in a bad life? Adorno Prize Lecture', Radical Philosophy, I76: 9-18.

Butler, Judith (20I2b), Parting Ways: Jewishness and the Critique of Zionism, New York: Columbia University Press.

Butler, Judith, and Gayatri Chakravorty Spivak (2007), Who Sings the 
I40 Butler and Ethics

Nation-State?: Language, Politics, Belonging, London and New York: Seagull Books.

Connolly, William (2005), The Ethos of Pluralization, Minneapolis: University of Minnesota Press.

Dean, Jodi (2009), Democracy and Other Neo-Liberal Fantasies: Communicative Capitalism and Left Politics, Durham, NC and London: Duke University Press.

Honig, Bonnie (2013), Antigone, Interrupted, Cambridge: Cambridge University Press.

Mills, Catherine (2007), 'Normative Violence, Vulnerability and Responsibility', differences: A Journal of Feminist Cultural Studies, I 8: 2, I 57-79.

Murphy, Ann (20I I), 'Corporeal Vulnerability and the New Humanism', Hypatia, 26: 3, 575-90.

Žižek, Slavoj (2006), 'Neighbors and Other Monsters: A Plea for Ethical Violence', in Slavoj Žižek, Kenneth Reinhard and Eric Santner, The Neighbor: Three Inquiries In Political Theology, Chicago: Chicago University Press, pp. I34-90. 